\title{
GIS applications for landslide susceptibility assessment: a case study in Iaşi County (Moldavian Plateau, Romania)
}

\author{
A. Grozavu ${ }^{1}$, M. C. Mărgărint ${ }^{1} \&$ C. V. Patriche ${ }^{2}$ \\ ${ }^{I}$ Department of Geography, Faculty of Geography and Geology, \\ Alexandru Ioan Cuza University of Iaşi, Romania \\ ${ }^{2}$ Romanian Academy, Iaşi Branch, Geography Team, Romania
}

\begin{abstract}
In Romania, landslides are a frequent reality in the geomorphologic landscape, particularly in the plateau units, with favourable conditions for the occurrence of such phenomena. This paper focuses on the applicability of landslide susceptibility assessment, by using a logistic regression approach, to a sector of Iaşi Cuesta in the Moldavian Plateau, where landslides happen to a significant extent. Ortophotoimages, topographical and geological maps were used as input data. The landslide inventory, multicriteria qualitative and quantitative analysis and GIS application have facilitated data processing and spatial visualization results. A database of landslide and landslide causative factors was constructed, consisting of several environmental data layers: land use as a qualitative variable and geomorphometrical parameters as quantitative variables. The latter were obtained from a DEM, at a resolution of 20x20 m, derived from 1:25,000 topographic maps. Application of this model at the scale of one small administrative unit (commune) shows that landslide occurrence is best explained by terrain slope, land use and altitude. The landslide susceptibility map reveals that terrains displaying high and very high susceptibility represent about $29 \%$ of the study area. The logistic regression model seems to be an adequate tool for the assessment of landslide susceptibility in an objective and quantitative manner, providing also parameters allowing the evaluation of the output quality. Starting from primary data sources at fine scales (1:5000), our model may be extended to other similar regions in the Moldavian Plateau.
\end{abstract}

Keywords: landslide susceptibility assessment, GIS application, logistic regression, geomorphometry, Moldavian Plateau, Romania. 


\section{Introduction}

In Romania, landslides are a frequent reality in the geomorphologic landscape, particularly in the Transylvanian Depression, Moldavian Plateau, Getic Plateau and Subcarpathians, where the conditions are favourable, determined mainly by the geological, geomorphological, hydrogeological and climatic background and by human factors. These affect mostly agricultural land, but also human settlements, infrastructure and economical facilities.

The national literature of this branch of science comprises studies devoted to these phenomena, which differ according to the objectives, level of approach, terminology and methodology [21]. In particular, after the great recrudescence of landslidings due to the pluviometric excess from 1970-1972 and the earthquakes from 1977, when all information about these phenomena came to be insufficient, complex studies of land use planning claimed deep knowledge of the landsliding process, foreseeing and prognoses. Landslide risk zoning constitutes the subject of several recent studies, [7, 18], and the results are rather heterogeneous due to different methods, scales, levels and types of zoning. At a legislative level, efforts are being made for the approach to landslides to be brought under the regulation of a general framework, by promoting and approving methodological guidelines concerning the elaboration and the content of landslide risk maps [14].

At international level, numerous researches are dedicated to the assessment of landslide risk and recent studies reveal different approaches: heuristic $[10,25$, 26], statistical (bivariate or multivariate statistics) [5, 24], probabilistic [12, 16] and deterministic $[2,15]$. Basic theories on landslide hazard prediction and risk assessment are summarized by Yin et al. [28]. It is worth mentioning the attempts towards the establishment of a common language and of standard procedures in landslide risk zoning, which may contribute to widening of their applications and facilitating the comparison among different geo-environmental contexts, such as the Guidelines proposed by JTC-1 the Joint Technical Committee on Landslides and Engineering Slopes [13]. An important issue is to relate the level of zoning to the required outcomes and to the scale of zoning [9].

This paper focuses on the applicability of landslide susceptibility assessment, by using a logistic regression approach, at the scale of one administrative unit (commune) where landslides have a significant extent.

\section{The study area}

The study area belongs to Moldavian Plateau which occupies eastern part of Romania, more precisely, it refers to the territory of Lungani commune (Iaşi County), with a surface of $63.37 \mathrm{~km}^{2}$, covering, in part, a sector of Iaşi Cuesta, along the right side of Bahluieţ river, fig. 1.

From morfostructural point of view, the Moldavian Plateau belongs to western borderline of the great East-European Platform with Oriental Carpathians orogen and the sedimentary counterpane is made up, to top, especially of Sarmatian deposits. 


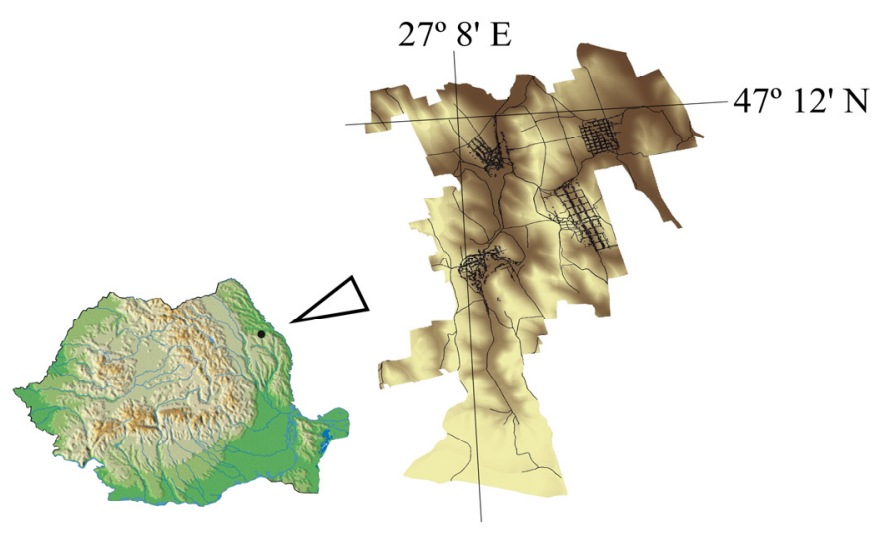

Figure 1: $\quad$ Location of the study area.

The lithology is represented by predominant marl-clay, sandstone and sand, in alternating layers of very different thickness from one region to another.

The climate is temperate-continental, the wide eastwards opening favouring the manifestation of some excessive continentalism traits (high temperature variations, uneven precipitation regime, frequent droughts).

From geomorphological point of view, large structural plateaus and narrow interfluves up to the intersection crests of slopes are characteristic, alternating with large valleys, asymmetric in most of the cases. Cuestas are characteristic, with their fronts affected by an increased frequency and intensity of the massmovement processes.

Among factors that trigger the process of landsliding the role played by the monocline structure, the alternation of the permeable with the impermeable rocks and the climatic factors (relative abundance of rainfall during the Mai-June period and heavy rains in summer) is obvious both for small and big landslides. In addition, in general landslides appear more frequently where man destroyed the vegetation by deforestation, intensive pasturing etc.

Landslides show great diversity of forms and thicknesses of deluvium, from superficial to landslides exceeding $30 \mathrm{~m}$ in depth. Most of the times, they are represented by complex associations, generalized on entire areas of slopes.

Concerning the age of landslides, it was concluded that there was a vast phase of modelling through landslide process located at the end of Pleistocene or in the transition period between Late Würm and warm period of postglacial (Preboreal). Massive landslides developed at that time are partially reactivated when pluviometric surpluses are reached [21]. According to Băcăuanu et al. [6] the deluvial processes of the Moldavian Plateau record a certain cyclicity, with intensification periods corresponding to the periods with excessive humidity, of almost 30 years.

At present, we may find a general stabilization tendency of landslides because of the raising with about 5-20 m of the denudation basis of slopes, as a result of the aggradation tendency of the flood-plains [8]. 


\section{Materials and methodology}

Conforming to the well-known principle "past and present are keys to the future" the characteristics of existing landslides can be used to evaluate the possible areas of future landslides [5].

The input data used for our study is represented by ortophotoimages, topographical maps, geological maps and specific information extracted from GUP (General Urban Plan) provided by local administrations.

Landslides and landslide causative factors database was constructed, consisting of several environmental data layers. Land use is the only qualitative variable considered in our study, while the rest of variables are represented by geomorphometrical parameters (slope angle, slope aspect, mean curvature, plan curvature, profile curvature, distance to drainage network), obtained from a digital elevation model (DEM), at a resolution of 20x20 m, derived from 1:25,000 topographic maps. Apart from geomorphometrical parameters, we also tested the influences of mean annual precipitations. Descriptive statistics for these variables are presented in table 1 . The surface lithology is relatively uniform throughout the region (dominated by Sarmatian clays) and the groundwater has a discontinuous character, being close to surface along the floodplains and greatly influenced by deficitary precipitation regime. Consequently, these factors were not included in our analysis.

Spatial analysis was performed using TNTmips 6.9 software [20] and ArcGIS 9.3 software [3], while statistical analysis was carried out using Excel 2003 and XLSTAT 2010 software [27].

The analysis of landslide susceptibility is based on application of the logistic regression model $[1,4,11,17]$. The logistic regression uses binary dependent variable and continuous and/or categorical predictors. It applies the maximum likelihood estimation after transforming the dependent variable into its natural

Table 1: Descriptive statistics for the landslide area and potential predictors.

\begin{tabular}{|l|c|c|c|c|}
\hline \multicolumn{1}{|c|}{ Variables } & Minimum & Maximum & Mean & $\begin{array}{c}\text { Std. } \\
\text { deviation }\end{array}$ \\
\hline Landslide area (ha) & 1.035 & 146.372 & 26.130 & 27.953 \\
\hline DEM $(\mathrm{m})$ & 61.921 & 312.678 & 131.921 & 44.769 \\
\hline Slope $\left({ }^{\circ}\right)$ & 0.027 & 18.060 & 7.376 & 3.640 \\
\hline Aspect $\left({ }^{\circ}\right)$ & 0.127 & 239.709 & 109.638 & 68.425 \\
\hline Distance to drainage network (m) & 0.144 & 977.096 & 166.421 & 132.275 \\
\hline Mean curvature (rad./m) & -0.450 & 0.531 & -0.006 & 0.136 \\
\hline Plan curvature (rad./m) & -0.390 & 0.418 & 0.001 & 0.080 \\
\hline Profile curvature (rad./m) & -0.505 & 0.310 & 0.007 & 0.090 \\
\hline Mean annual precipitations (mm/yr.) & 480.752 & 580.426 & 519.692 & 16.982 \\
\hline Land use (landslides density) & 0.000 & 1.000 & 0.180 & 0.267 \\
\hline
\end{tabular}


logarithm, estimating the probability of a certain event to occur [5, 23]. The logistic regression model is described by the following equation:

$$
P=\frac{1}{1+e^{-z}}
$$

where, $P$ is the probability of an event (landslide) to occur, which varies from 0 to 1 on an S-shaped curve; $z$ is a linear combination of predictors $\left(x_{1} \ldots x_{\mathrm{n}}\right)$ :

$$
z=b_{0}+b_{1} x_{1}+b_{2} x_{2}+\ldots+b_{n} x_{n}
$$

where, $b_{0}$ is the intercept of the model and $b_{1} \ldots b_{\mathrm{n}}$ are the regression coefficients.

It is generally recommended to use the "seed cells" approach $[19,22]$, that is to extract predictors values form points situated in the vicinity of landslides polygons and not from landslide area, where the fragmented terrain causes important variations of geomorphometrical parameters. This approach was not applied in our study for the following reasons: landslides often cover an entire slope facet, the geomorphometrical parameters changing significantly outside the landslide area; the DEM derived on the basis of 1:25,000 topographical maps renders a more general terrain configuration and therefore, the extraction of predictors values from landslide areas themselves in not influenced by its real

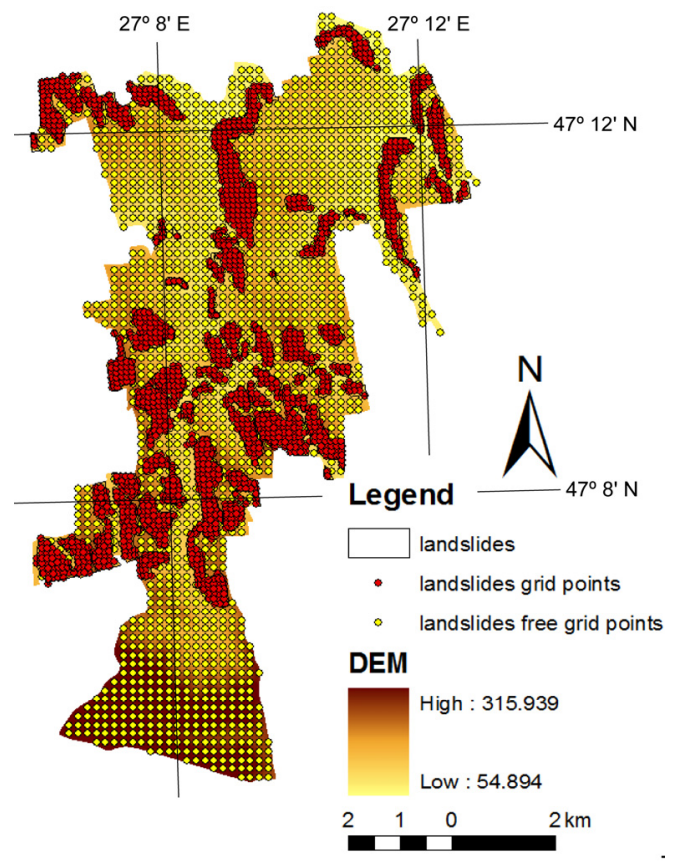

Figure 2: Locations of grid points inside and outside the landslide area. 
fragmentation. Instead, we generated a total number of 3040 equally distanced grid points for the landslide and landslide free areas, fig. 2. The points density is higher in the landslide area because of the need to obtain equal samples for the landslide and the landslide free areas. Land use, the only categorical predictor in our analysis, was transformed into a quantitative predictor by computing the landslide density for this parameter [5].

\section{Results and discussion}

\subsection{Landslide susceptibility zoning}

For susceptibility zoning the key parameter is the landslide inventory and its level and quality also depends on understanding the role played by predisposing factors on landsliding [13].

Landslides affect about 1542 ha, representing $24.6 \%$ of the commune surface, occurring especially on cuesta fronts and being in different evolution stages. The database included 59 landslides delimited by means of large scale mapping $(1: 25,000,1: 5000)$ or by using aerial photographs and also by field studies in order to verify the size, shape and especially the state of activity of landslides.

Most of landslides are detrusive, inconsistent, with depths between 2-10m and the relatively stabilized ones are predominant, affected on sporadic areas by active landslides.

The Pearson correlation matrix computed for potential predictors, as shown in table 2 , reveals that there is a certain amount of co-linearity among variables, which imposes their selection.

The standardized regression coefficients show that landslides occurrence is best explained by terrain slope, land use and altitude. Running the XLSTAT 2010 module, the mean curvature is automatically eliminated due to its multi colinearity. We further eliminated the mean annual precipitations and the terrain exposition on the basis of Chi-square (Wald) test. The output from remaining

Table 2: $\quad$ Pearson correlation matrix for potential predictors.

\begin{tabular}{|c|c|c|c|c|c|c|c|c|c|}
\hline & DEM & SLOPE & ASPECT & DIST & MEANC & PLANC & PROFILEC & PRECIP & LANDUSE \\
\hline DEM & $\mathbf{1 . 0 0 0}$ & 0.144 & -0.111 & 0.245 & 0.226 & 0.048 & -0.297 & 0.870 & -0.143 \\
\hline SLOPE & 0.144 & $\mathbf{1 . 0 0 0}$ & 0.130 & -0.063 & 0.041 & 0.040 & -0.025 & 0.048 & 0.280 \\
\hline ASPECT & -0.111 & 0.130 & $\mathbf{1 . 0 0 0}$ & -0.132 & 0.002 & 0.019 & 0.013 & -0.230 & 0.290 \\
\hline DIST & 0.245 & -0.063 & -0.132 & $\mathbf{1 . 0 0 0}$ & 0.344 & 0.220 & -0.321 & 0.211 & -0.164 \\
\hline MEANC & 0.226 & 0.041 & 0.002 & 0.344 & $\mathbf{1 . 0 0 0}$ & 0.767 & -0.823 & 0.099 & -0.075 \\
\hline PLANC & 0.048 & 0.040 & 0.019 & 0.220 & 0.767 & $\mathbf{1 . 0 0 0}$ & -0.266 & -0.025 & -0.044 \\
\hline PROFILEC & -0.297 & -0.025 & 0.013 & -0.321 & -0.823 & -0.266 & $\mathbf{1 . 0 0 0}$ & -0.171 & 0.074 \\
\hline PRECIP & 0.870 & 0.048 & -0.230 & 0.211 & 0.099 & -0.025 & -0.171 & $\mathbf{1 . 0 0 0}$ & -0.306 \\
\hline LANDUSE & -0.143 & 0.280 & 0.290 & -0.164 & -0.075 & -0.044 & 0.074 & -0.306 & $\mathbf{1 . 0 0 0}$ \\
\hline
\end{tabular}


6 variables was compared to the output from the model using only the 3 predictors mentioned above. We found that the two statistical models are very similar. Because using 6 predictors instead of 3 does not significantly improve the model, we decided to further use the latter.

From the spatial distribution of landslide susceptibility, displayed in fig. 3, we notice that indeed the terrain slope plays a major role in explaining landslides spatial distribution. Landslide susceptibility index for the study region is characterized by a mean value of 0.375 and a standard deviation of 0.332 . The regression coefficients show that landslides occurrence are positively related to terrain slope and land use and negatively related to altitude, as shown in table 3. The quality regression parameters indicate a fairly good model, with a Root Mean Square Error of 0.348 , table 4. The percentage of correctly classified points is $81.59 \%$ in the landslide area and $84.02 \%$ in the landslide free area, while the overall prediction accuracy is $82.80 \%$, table 5 .

The classification of landslide susceptibility was based on natural breaks method (Jenks), which identifies the class breaks that best group similar values and maximizes the differences between classes.

Table 3: $\quad$ Logistic regression coefficients.

\begin{tabular}{|c|c|c|c|c|}
\hline $\begin{array}{c}\text { Intercept / } \\
\text { Predictors }\end{array}$ & $\begin{array}{c}\text { Regression } \\
\text { coefficients }\end{array}$ & $\begin{array}{c}\text { Standard } \\
\text { error }\end{array}$ & Wald Chi-Square & $\operatorname{Pr}>\mathrm{Chi}^{2}$ \\
\hline Intercept & -1.906 & 0.195 & 95.141 & $<0.0001$ \\
\hline DEM & -0.020 & 0.001 & 175.113 & $<0.0001$ \\
\hline Land use & 5.088 & 0.327 & 242.409 & $<0.0001$ \\
\hline Slope & 0.506 & 0.020 & 625.169 & $<0.0001$ \\
\hline
\end{tabular}

Table 4: Quality parameters of the logistic regression model.

\begin{tabular}{|c|c|}
\hline Quality parameters & Values \\
\hline-2 Log(Likelihood) & 2339.672 \\
\hline $\mathrm{R}^{2}$ (McFadden) & 0.445 \\
\hline $\mathrm{R}^{2}$ (Cox and Snell) & 0.460 \\
\hline $\mathrm{R}^{2}$ (Nagelkerke) & 0.614 \\
\hline Area under ROC curve & 0.91 \\
\hline RMSE & 0.348 \\
\hline
\end{tabular}

Table 5: Numbers and percentages of the correctly classified points.

\begin{tabular}{|c|c|c|c|c|}
\hline from $\backslash$ to & 0 & 1 & Total & $\%$ correct \\
\hline 0 & 1272 & 242 & 1514 & $84.02 \%$ \\
\hline 1 & 281 & 1245 & 1526 & $81.59 \%$ \\
\hline Total & 1553 & 1487 & 3040 & $82.80 \%$ \\
\hline
\end{tabular}




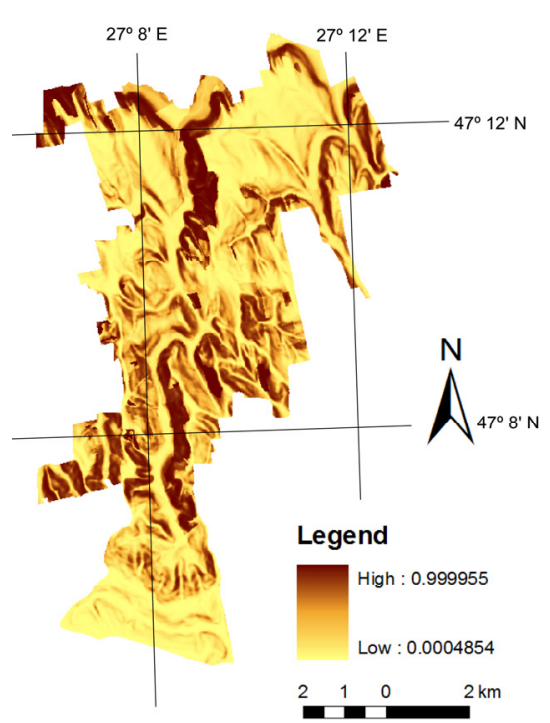

Figure 3: Spatial distribution of landslide susceptibility.

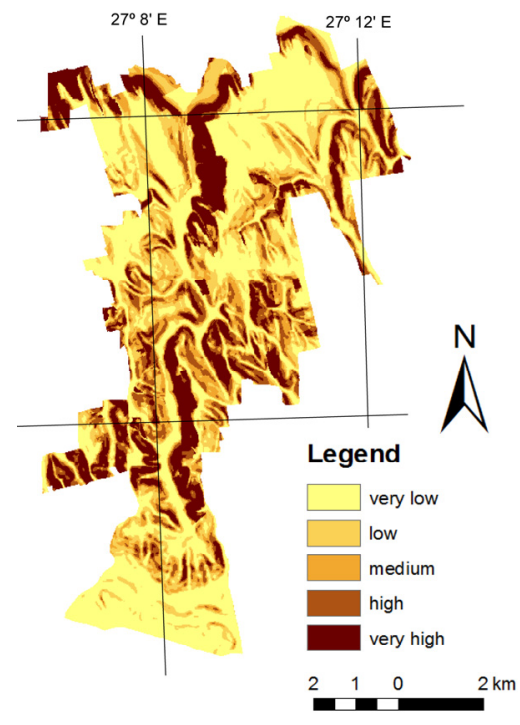

Figure 4: Classified landslide susceptibility.

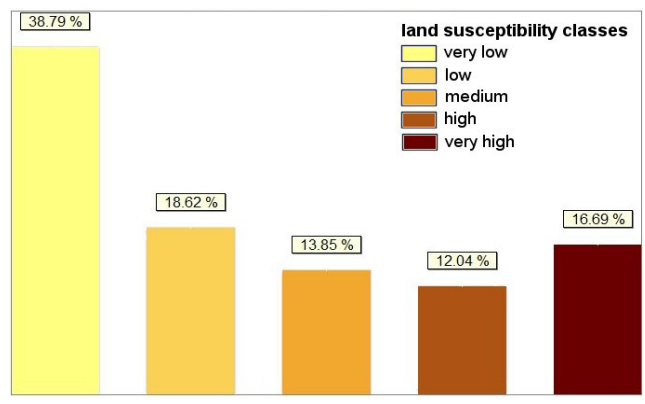

Figure 5: Percentages of landslide susceptibility classes.

Spatial distribution of continuous landslide susceptibility is given in fig. 3 and classified landslide susceptibility, in fig. 4. The latter shows that more than half of the study area is characterized by very low and low landslide susceptibility, while the terrains displaying high and very high susceptibility represent about $29 \%$ of its surface.

\subsection{Exposure to landslide risk}

The human elements subject to landslide risk are the buildings from the 4 villages in the study area and the roads network (mostly agricultural roads), 
which were digitised using the 1:5000 topographic maps. We inventoried 1640 buildings with a total surface of 82.516 ha and $170 \mathrm{~km}$ of roads.

Overlaying the considered human elements (buildings and roads), exposed to landslide risk, we found that about $14 \%$ of buildings (11.6 ha) are situated in high and very high landslide susceptibility areas and about $15 \%$ of the road network $(25 \mathrm{~km})$ crosses these landslide susceptibility classes, figures 6,7 and 8 .

To refine these results in the future, more data related to elements at risk should be collected, including population and the replacement value of buildings and roads, as well as the value of agricultural crops.

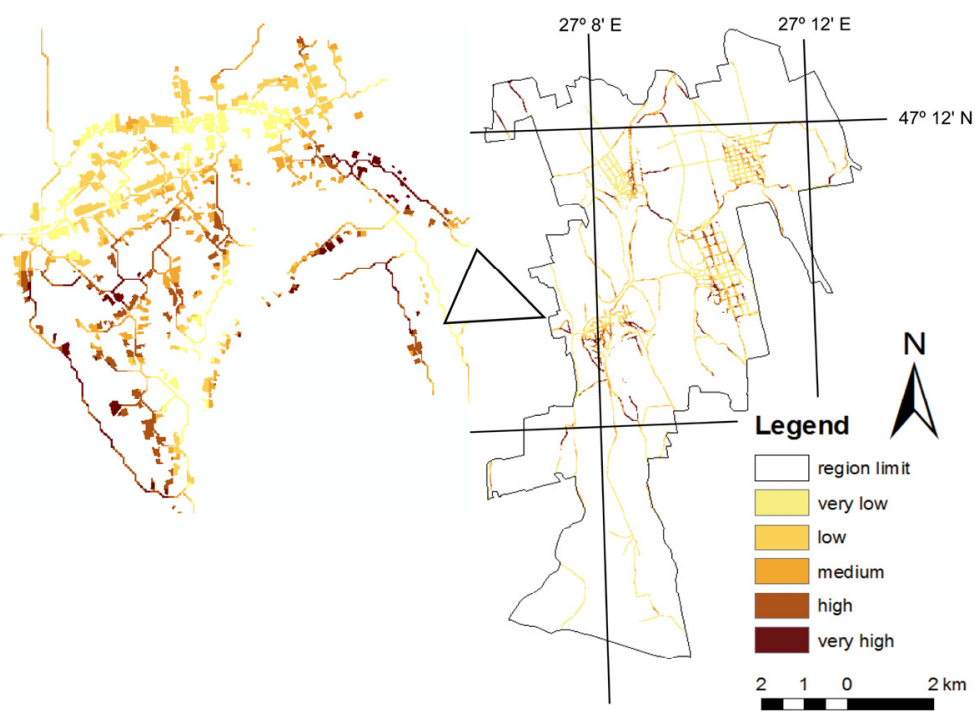

Figure 6: Landslide susceptibility classes for buildings and roads.

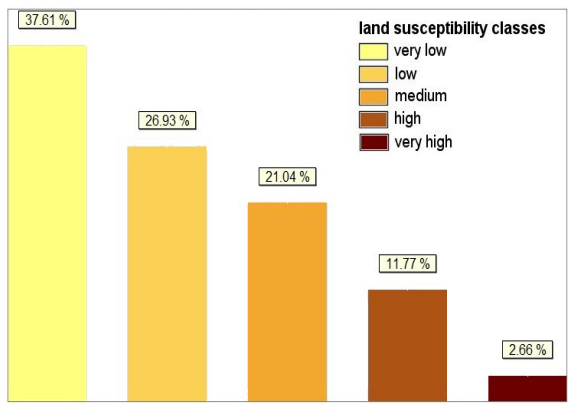

Figure 7: Percentages of landslide susceptibility classes at building locations.

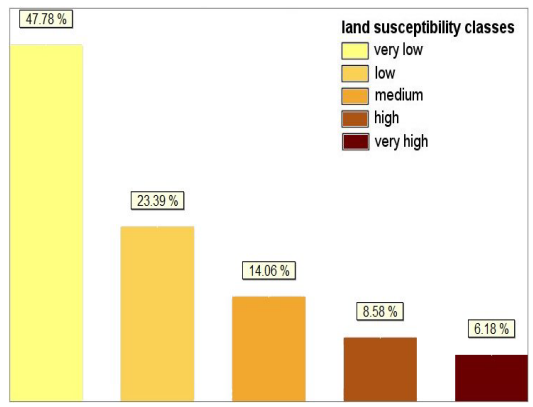

Figure 8: Percentages of landslide susceptibility classes along the road networks. 


\section{Conclusions}

Landslide susceptibility zoning can be a powerful tool to improve land-use planning, an efficient way to reduce future negative consequences caused by landslides.

The logistic regression approach seems to be an adequate tool for the assessment of landslide susceptibility in an objective and quantitative manner, providing also parameters permitting evaluation of output quality.

Application of this model at the scale of one small administrative unit (commune), where landslides represent a frequent geomorphologic phenomenon, shows that landslides occurrence is best explained by terrain slope, land use and altitude. In addition, significant percentages of the landslides and of areas with high and very high landslide susceptibility are mainly located on slopes exposed towards west and north-west, corresponding to cuesta fronts.

Generally, in the study area, the settlements and the road network avoided slopes exposed to landslide risk, but there still are numerous areas obviously displaying such a risk. Even though most of the roads are for agricultural purposes, some road sectors linking villages are in high and very high susceptibility areas.

The medium landslide susceptibility class should be included as an area category where buildings must have increased safety measures. Further development of the infrastructure should avoid areas with high and very high landslide susceptibility.

Starting from the primary data sources at fine scales (1:5000), our model may be extended to other settlements situated in similar geological and geomorphological conditions in the Moldavian Plateau.

Furthermore, a complete landslide risk zoning requires both landslide hazard zoning and the estimation of community vulnerability to landslides. For landslide hazard zoning an estimated frequency (annual probability) of landsliding is assigned to each category of the landslide susceptibility map. The evaluation of community vulnerability to landslides is accomplished by also taking into account economic and social indicators.

\section{References}

[1] Afifi, A.A. \& Clark, V., Computer aided multivariate analysis, Chapman Hall: London, 1998.

[2] Aleotti, P. \& Chowdhury, R., Landslide hazard assessment: summary review and new perspectives. Bulletin of Engineering Geology and the Environment, 58, pp. 21-44, 1999.

[3] ArcGIS Desktop 9.3 Help, Environmental Systems Research Institute (ESRI), http://webhelp.esri.com/arcgisdesktop/9.3

[4] Atkinson, P.M. \& Massari, R., Generalized linear modeling of susceptibility to landsliding in the central Apennines, Italy. Computers and Geosciences, 24(4), pp. 373-385, 1998. 
[5] Bai, S.-B., Wang, J., Lü, G.-N., Zhou, P.-G., Hou, S.-S. \& Xu, S.-N., GISbased logistic regression for landslide susceptibility mapping of the Zhongxian segment in the Three Gorges area, China. Geomorphology, 115, pp. 23-31, 2010.

[6] Băcăuanu, V., Barbu, N., Pantazică, M., Ungureanu, Al. \& Chiriac, D., Podişul Moldovei. Natură, om, economie, Editura Ştiinţifică şi Enciclopedică: Bucureşti, 1980.

[7] Bălteanu, D., Chendeş, V., Sima, M. \& Enciu, P., A country level spatial assessment of landslides in Romania. Proc. of the IAG Regional Conference on Geomorphology. Landslides, floods and global environmental change in mountain regions 2008. ed. D. Bălteanu, Editura Universitară: Braşov, pp. 19, 2008.

[8] Brânduş C., Grozavu A., Natural Hazard and Risk in Moldavian Tabeland. Revista de Geomorfologie, 3, Bucureşti, pp. 15-23, 2002.

[9] Cascini, L., Applicability of landslide susceptibility and hazard zoning at different scales. Engineering Geology, 102, pp. 164-167, 2008.

[10] Castellanos Abella, E.A. \& Van Westen, C.J., Qualitative landslide susceptibility assessment by multicriteria analysis: A case study from San Antonio del Sur, Guantánamo, Cuba. Geomorphology, 94, pp. 453-466, 2008.

[11] Dai, F.C., Lee, C.F. \& Xu, Z.W., Assessment of landslide susceptibility on the natural terrain of Lantau Island, Hong Kong. Environmental Geology, 40(3), pp. 381-391, 2001.

[12] Demoulin, A. \& Chung, C.-J.F., Mapping landslide susceptibility from small datasets: A case study in the Pays de Herve (E Belgium). Geomorphology, 89, pp. 391-401, 2007.

[13] Fell, R., Corominas, J., Bonnard, C., Cascini, L., Leroi, E. \& Savage, W.Z., Guidelines for landslide susceptibility, hazard and risk zoning for land use planning. Engineering Geology, 102, pp. 85-98, 2008.

[14] Government Decree no. 447 from April 10, 2003, regarding the approval of the methodological standards concerning elaboration and the content of the landslides and floods risk maps. Monitorul Oficial, Part I, no. 305 from 07/05/2003.

[15] Guzzetti, F., Carrara, A., Cardinali, M. \& Reichenbach, P., Landslide hazard evaluation: a review of current techniques and their application in a multi-scale study, Central Italy. Geomorphology, 31, pp. 181-216, 1999.

[16] Kaynia, A.M., Papathoma-Köhle, M., Neuhäuser, B., Ratzinger, K., Wenzel, H. \& Medina-Cetina, Z., Probabilistic assessment of vulnerability to landslide: Application to the village of Lichtenstein, Baden-Würtemberg, Germany. Engineering Geology, 101, pp. 33-48, 2008.

[17] Lee, S. \& Min, K., Statistical analysis of landslide susceptibility at Yongin, Korea. Environmental Geology, 40, pp. 1095-1113, 2001.

[18] Micu, M., Landslide risk assessment in the Subcarpathians between the Buzău and the Teleajen rivers. IAG Regional Conference on Geomorphology. Landslides, floods and global environmental change in 
mountain regions 2008 - field guidebook, ed. D. Bălteanu, Editura Universitară: Braşov, pp. 111-114, 2008.

[19] Nefeslioglu, H.A., Duman, T.Y. \& Durmaz, S., Landslide susceptibility mapping for a part of tectonic Kelkit Valley (Eastern Black Sea region of Turkey). Geomorphology, 94, pp. 410-418, 2008.

[20] Reference Manual for the TNT products V6.4, Lincoln, MicroImages Inc., 2000.

[21] Surdeanu, V., The study of landslides. Revista de Geomorfologie, 1, pp. 97-102, 1997.

[22] Süzen, M.L. \& Doyuran, V., Data driven bivariate landslide susceptibility assessment using geographical information systems: a method and application to Asarsuyu catchment, Turkey. Engineering Geology, 71, pp. 303-321, 2004.

[23] Süzen, M.L. \& Doyuran, V., A comparison of the GIS based landslide susceptibility assessment methods: multivariate versus bivariate. Environmental Geology, 45, pp. 665-679, 2004.

[24] Thiery, Y., Malet, J.-P., Sterlacchini, S., Puissant, A. \& Maquaire, O., Landslide susceptibility assessment by bivariate methods at large scales: Application to a complex mountainous environment. Geomorphology, 92, pp. 38-59, 2007.

[25] Van Westen, C.J., Rengers, N. \& Soeters, R., Use of geomorphological information in indirect landslide susceptibility assessment. Natural Hazards, 30, pp. 399-419, 2003.

[26] Van Westen, C.J., Van Asch, T.W.J. \& Soeters, R., Landslide hazard and risk zonation: why is it still so difficult?. Bulletin of Engineering Geology and the Environment, 65, pp. 167-184, 2006.

[27] XLSTAT Tutorial, http://www.xlstat.com/en/support/tutorials/

[28] Yin, K., Chen, L. \& Zhang, G., Regional Landslide Hazard Warning and Risk Assessment. Earth Sciences Frontiers, 14(6), pp. 85-97, 2007. 